\title{
Testicular Cancer pN2 TNM Finding v8
}

National Cancer Institute

\section{Source}

National Cancer Institute. Testicular Cancer pN2 TNM Finding v8. NCI Thesaurus. Code C140223.

Testicular cancer with metastasis with a lymph node mass larger than $2 \mathrm{~cm}$ but not larger than $5 \mathrm{~cm}$ in greatest dimension; or more than five nodes positive, none larger than $5 \mathrm{~cm}$; or evidence of extranodal extension of tumor. (from AJCC 8th Ed.) 